\title{
Zumurrud (emerald): Medicinal Potential of a Gemstone from Jawaharat-i-tis 'a (navratan), in the Perspective of Unani Medicine
}

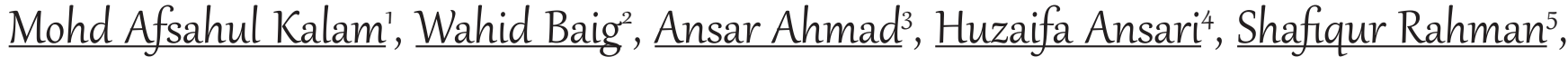 \\ Abdul Haseeb $^{6}$ \\ ${ }^{1}$ Research Officer Unani \& Lecturer, ${ }^{3}$ Prof., ${ }^{4,5,6}$ PG Scholars (M.D), Department of IImul Advia, Regional Research Institute of \\ Unani Medicine, Kashmir University, Habak, Naseembagh Campus, Hazratbal, Srinagar, Jammu and Kashmir, India. \\ ${ }^{2}$ Unani Physician and Ex-Medical Officer Govt. of Rajasthan, Jaipur, Rajasthan, India. \\ DOI: https://doi.org/10.24321/2394.6547.202102
}

I $\quad \mathbf{N} \quad \mathbf{F} \quad \mathbf{O}$

Corresponding Author:

Mohd Afsahul Kalam, Department of Ilmul Advia, Regional Research Institute of Unani Medicine, Kashmir University, Habak, Naseembagh Campus, Hazratbal, Srinagar, Jammu and Kashmir, India. E-mail Id:

afsahnium@gmail.com

Orcid Id:

https://orcid.org/0000-0002-8071-0488

How to cite this article:

Kalam MA, Baig W, Ahmad A, Ansari H, Rahman $S$, Haseeb A. Zumurrud (emerald): Medicinal Potential of a Gemstone from Jawaharat-i-tis 'a (navratan), in the Perspective of Unani Medicine. J Adv Res Ayur Yoga Unani Sidd Homeo. 2021; 8(1\&2): 5-9.

Date of Submission: 2021-05-24

Date of Acceptance: 2021-06-15
$\begin{array}{llllllll}\mathbf{A} & \mathbf{B} & \mathbf{S} & \mathbf{T} & \mathbf{R} & \mathbf{A} & \mathbf{C} & \mathbf{T}\end{array}$

Emeralds are transparent and coloured varieties of beryl mineral. It is categorised as a precious and valuable stone. It has a beautiful, intense, and radiant green colour. Emerald is one of the most expensive gemstones due to its bright green colour, durability, and rare availability. A fine and top quality emerald is more valuable than diamonds. Basically, it is found in gold mines and takes a long period of 21 years to reach its complete formation. Emerald has been used for medicinal purpose from ancient time. In Babylon (the oldest gem market), the fine quality emerald crystal gem was dedicated to the goddess Venus. In the case of emerald, it is believed that it represents immortality and faith. In the Unani system of medicine, it is used as a vital organ tonic, cicatrizant, diuretic, lithotriptic, antidote, eye tonic, blood purifier etc. It is used in cases of anuria and some psychic conditions like stress and anxiety. It stimulates the use of greater mental capacity and enhances memory. No pharmacological studies on emerald have been done yet, so this article has been compiled for its medicinal uses in the perspective of Unani medicine to provide a lead for pharmacological studies on this precious gemstone.

Keywords: Unani Medicine, Zumurrud, Emerald. Gemstone, Jawaharat-i-tis 'a, Epilepsy, Palpitation

\section{Introduction}

The Unani System of Medicine provides health care by various natural sources like plants, minerals, and animal substances, called Mawalid-i-Thalatha. ${ }^{1}$ Stones, particularly gemstones, have been a prized possession of human beings from time immemorial for their lustre as well as their presumed healing properties. It remains to be seen whether such traditional medicinal uses can be validated by modern science. Emerald, ruby, and sapphire are all considered as precious gemstones which come under Navratnas and are used for medicinal purpose in Ayurvedic and Unani System of Medicine. Zumurrud or Emerald is a green colour stone. Its colour is due to the presence of trace amounts of the elements, chromium or vanadium. ${ }^{2}$ 
The word "EMERALD" is derived from the old French word "esmeraude" and the Middle English word "emeraude"; from the Vulgar Latin word "esmaralda/ esmaraldus", a variant of Latin "smaragdus", which originated in Ancient Greek (smaragdos means Green gem). Emeralds are the transparent and intense radiant green coloured varieties of beryl mineral and are much valued as precious stones. Commonly emerald is known as "Panna" in Hindi and "Zumurrud" in Arabic. One more stone is known as Zabarjad (peridot) is often confused with Zumurrud (emerald). ${ }^{3}$ Zumurrud or Panna of high quality is a dark green coloured, transparent stone with a velvety reflection. ${ }^{3}$ The top quality emerald is considered more valuable than diamonds due to its green colour, durability and rarity, while the old Zumurrud is black in colour and hard in nature. It is found under the earth and obtained from the gold mines in Western Asia, especially on Jabl-i-Misr near the Hills of Maqtam and Bajat, and also from Sudan. ${ }^{3,4}$ The mines which are found in Sudan are known as Cleopatra's mines. The description given in Unani classical books as the basic matter of Zumurrud is gold. The dryness and hardness of the mines convert gold into precious stones called Zumurrud. The formation of Zumurrud takes in goldmines 21 years. ${ }^{5}$ Zumurrud represents immortality and faith, hence in the ancient civilisations like Babylon (400 B.C.), fine quality Zumurrud was dedicated to the Goddess Venus. In the Indian civilisation, the Panna was one of the Navagrah stones (stones that represents the nine planets that have a cosmic influence on all earthlings). It represented Mercury which is related to business, communication, intelligence, and education. In Vedas, it is called Panna. It is described in Vedas that it evokes the desire of eating cold and sweet food. It is also used in piles, Du'f Haḍm, and jaundice.

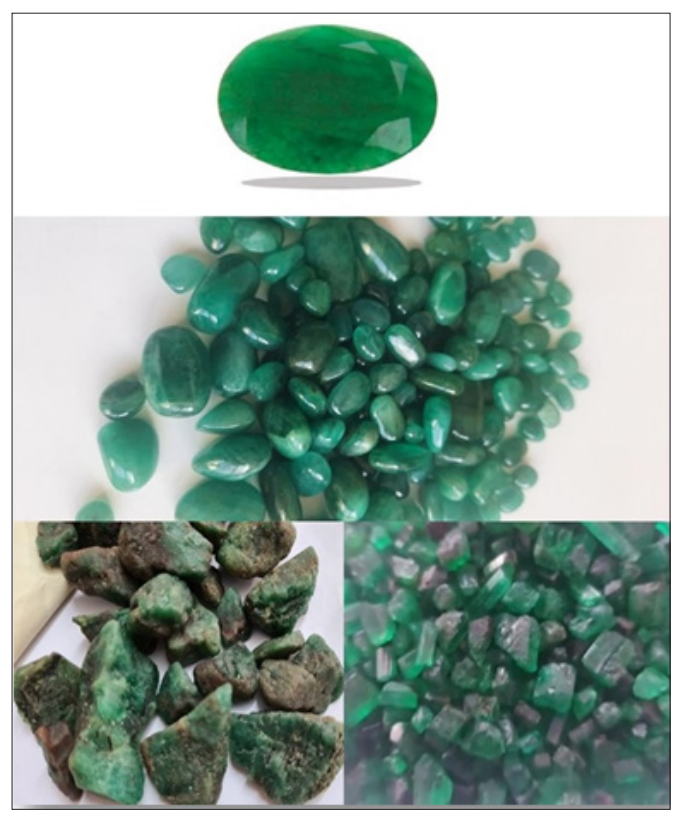

Figure I.Various Forms of Zumurrud (Emerald)

\section{Material and Methods}

Numerous authentic publications, both printed and electronic, were searched for the collection of the data on types, therapeutic uses in Unani Medicine, mineralogy, and pharmacological studies, etc. on Zumurrud (emerald). All relevant articles up to 2020 were obtained from 14 Unani books, 02 review papers, and 01 English book. Genuine materials published in PubMed, Science Direct, Google Scholar, and Research Gate were referred to assemble all the latest data. Appropriate Unani terminologies were taken from the Standard Unani Medical Terminology published by the Central Council for Research in Unani Medicine in collaboration with the World Health Organization. The images were collected by the author from Rajasthan, India.

\section{Types of Zumurrud}

In the classical literature of Unani medicine, emerald is classified into seven types on the basis of its colour. They are mentioned as below:

1. Zumurrud Zababi: its colour resembles a green fly, so it is called Zababi (fly coloured). 4 It is also called "Sa'idi Zumurrud" because it is obtained from Sa'id-i-Misr (Egyptian mines). ${ }^{6}$

2. Zumurrud Rehani: Its colour is similar to the leaf of a plant namely Rehan (Ocimum sanctum). It is also known as "Zumurrud Nau". ${ }^{4}$

3. Zumurrud Fistaqi: The colour is greenish-black like Pista or Fistaq (Pistacia vera). It is also known as "Zumurrud Kohna" meaning old emerald. ${ }^{4,6}$

4. Zumurrud Silqi: The colour is the same as that of the leaf of Chukandar (Beta vulgaris)..$^{4,6}$

5. Zumurrud Zangari: It seems like verdigris (copper acetate) ${ }^{4}$

6. Zumurrud Kurrathi: The colour seems like the leaf of Gandana or Kurrath (Allium ascalonicum). ${ }^{4}$

7. Zumurrud Sabuni: It is whitish-green in colour and is considered to be the worst quality. ${ }^{4}$

History: According to Azam Khan, "it produces blindness in snakes, if kept in front of snakes". Mughal king Humayun, on the basis of experiments, wrote in his book "Prototype of stones", that no such effect can be seen on snakes hence this hypothesis is not true. ${ }^{6}$ It is believed that if someone wears a Zumurrud stone set on gold plated ring on his/ her little finger, he/ she gains huge popularity in the world, because of this fact, royal families put Zumurrud ring on their beloved ones after birth. In ancient books, it is written that Zumurrud protects from plague and seizures. If Zumurrud is put on as a necklace in case of a seizure at the time of the episode, it not only stops them but also prevents further episodes throughout the course of life. ${ }^{5,6}$

Distribution: The mines of Zumurrud are found in the Red Sea in Egypt. The preferred best quality is found in 
Columbia. In India, it occurs in Bubani and Rajgarh mines in Ajmer, Kalaguman, Tekhi mines in Udaipur, and from Birmaharajapura to Patangarh in Kalahandi in Orissa. It is also found in Karnataka, Andhra Pradesh, Tamil Nadu, Bihar, and Jammu and Kashmir.

\section{Mutaradifat (Vernacular Names)}

- $\quad$ Arabic: Hajr-i-Karim, Zumurrud ${ }^{4}$

- Bengali: Pana ${ }^{4}$

- English: Emerald ${ }^{4}$

- Hindi: Panna ${ }^{5,8}$

- Latin: Smargadus

- Persian: Zumurrud

- Sanskrit: Harit Ratan, Harida Ratan, Marakatha Mani, Tarksiya

- $\quad$ Sindhi: Zumurrud ${ }^{4}$

- Tamil: Maragatham

Mizaj (Temperament): According to the theory of Unani medicine, the drugs work in the body by their specific temperament, some of them are hot and some cold, associated with secondary functions like dryness or moistness. Aristotle, told that, Zumurrud acts with its cold and dry temperament, ${ }^{3}$ some physicians considered it cold in 2nd degree and dry in 3rd degree ${ }^{5,7}$ while some says it hot and dry in 1st degree, ${ }^{5}$ cold with intense dry; and hot and dry also.

Nafa' Khas (Main Action): Muqawwi Qalb-wa-Dimāgh (cardiac and brain tonic), Muqawwi-i-Harārat-i-Ghariziya (tonic of innate body heat).

Af'al (Functions): It has Mufarrih Aza-i-Raisa (exhilarant of vital organs), Muqawwi-i-Aḍa-i-Raīs (tonic to vital organs), ${ }^{4,9}$ Muqawwi-i-Hararat Ghariziya (tonic to innate heat), Mun'ish-i-Harārat Ghariziya (stimulant of innate heat), Muqawwi-i-Mi'da (stomachic), Muqawwi-i-Jigar (liver tonic), Muqawwi-i-Gurda (renal tonic), ${ }^{9}$ Mujaffif (siccative), Mudirr-i-Bawl (diuretic), Mufattit-i-Hasāt (lithotriptic), Taryāq-i-Samoom (antidote of poisons), ,3 Muqawwi-i-Basar (eye tonic), and Musaffi-i-Khoon (blood purifier) ${ }^{7}$ properties.

Forms and Method of Use: In compound formulations, emerald is used in various forms like Zumurrud Sāeda, Zumurrud Mahlool (fine powder), and Kushta (calx) for oral use and Surma (corylum) for local/topical use. It is also worn on the neck as a pendant for medicinal as well as ornamental purposes. Mostly its fine powder after Sahaq-iBaligh (obtained from rubbing continuously for a long time) and Kushta (calx) prepared by a specific method are used medicinally in various compounds such as Yaquti, Khamira etc. ${ }^{4}$ The method of preparation of Kushta is as follows.

1 tola (10 g) Zumurrud is taken along with Arq-i-Gulāb (rose water) and made into tablet form by rubbing it in kharal (mortar and pestle). Then the tablets are put in between
Maghz Gheekawār (Aloe vera) into a buta (two clay pots). Now the buta is covered and enclosed with the help of soil and cloth, for which a special term is used known as Kapdawti. Now the buta is put into a pit and is heated with the help of 12 ser UPLE. Once it cools down, the drug is collected from the buta in oxide form called Kushta. ${ }^{9}$

\section{Iste 'malat (Therapeutic Uses)}

It is used to treat several ailments like Yaraqan (Jaundice), Khafaqan (palpitation), Nafthud Dam (hemoptysis), Dātul Janb (pleurisy), Dātur Riya (pneumonia), Ishāl-i-Damwi (bloody diarrhoea), Istisqā (ascites), Du'f Mi'da (stomach weakness), Du'f Jigar (hepatargia), and Du'f Gurda (renal weakness). ${ }^{4}$ Zumurrud is effective against psychiatric conditions like anxiety and stress. It has lithotriptic action hence used in renal and bladder stones. It is used for the purification of blood and in urinary diseases, and also for some kinds of cardiovascular diseases. It is effective against pulmonary tuberculosis and gives corroboration to the heart, brain, liver, and kidneys. It is effective in Ihtibas$i$-Bawl (anuria). Emerald is also useful in the treatment of deafness and dumbness. It is reported that emerald can be used to enhance memory and stimulate the use of greater mental capacity. It helps combine intelligence with discernment, allowing for the choice of right action. It is very useful in cases of bites of poisonous insects and animals. ${ }^{3,7}$ Its uses in various ailments for the treatment purpose are described below:

Sar' (Epilepsy): Wearing it as a pendant or a ring before the onset of seizure prevents epileptic fits. ${ }^{3,7}$

Intishar Shā'r (Hair loss): Fine powder of Zumurrud mixed with other drugs (creams and ointments) produces good results in Ganj (chronic baldness), and Huzāz (dandruff). ${ }^{3,6}$

Du'f Basar (Low eye vision): The Kohl (Surma) of Zumurrud acts as Muqawwi-i-Basar (eye tonic) and is useful in Sabal (pannus). $6,7,10$

Amrad-i-Qalb: Taking orally and/ or wearing as a ring or pendant is useful for strengthening the heart, its powder is very useful for the treatment of palpitation. ${ }^{6}$

Amrad-i-Riya (Diseases of the lung): Taking powder orally and/ or wearing it as a ring or pendant is useful for lung diseases, e.g. Nafthud Dam (haemoptysis), Dātul Janb (pleurisy), Dātur Riya (pneumonia) etc. ${ }^{6}$ IbnBaitar has mentioned that it is very useful to cure haemoptysis if taken orally. ${ }^{3}$ According to Ibn Masoya, its pendant is applied to cure haemoptysis.

Amrad-i-Mi'da wa Am'a (Gastrointestinal diseases): With reference to Ibn Masoya, IbnBaitar has mentioned its usefulness in case of bloody diarrhoea, if taken orally. ${ }^{3}$ Taking powder orally and wearing a ring or pendant is useful for strengthening the stomach and liver. ${ }^{6}$ 
Amrad-i-Bawl (Diseases of Urinary System): Zumurrud is taken as a powder to cure cholelithiasis, vesical stone, and retention of urine etc. ${ }^{6}$

Quruh, Juruh wa Buthur (Wound, ulcer, and boils) etc.: A fine powder of Zumurrud mixed with creams and ointments produces good results in chronic wounds. ${ }^{3}$

Juzam (Leprosy): A fine powder of Zumurrud mixed with creams and ointments produces good results in leprosy. The powder is also used orally for the same cause. ${ }^{6} \mathrm{~A}$ similar stone called Zabarjad (peridot) is also useful in Juzam (leprosy). ${ }^{3}$

Poisoning: $60 \mathrm{mg}$ of powder acts as an antidote in cases of poisoning if used before the poison reaches up to the heart. The dose of $500 \mathrm{mg}$ of Zumurrud prevents the harmful effects of poison. ${ }^{6}$

Miqdar Khurak (Dose): The dose is $250 \mathrm{mg}$ - $3.5 \mathrm{gm}$ in the form of powder. In the case of poisoning, $500 \mathrm{mg}$ is used as an antidote; in cases of Nafthud Dam, $250 \mathrm{mg}$ is taken orally. ${ }^{6}$

Hakim Najmul Ghani has mentioned the dose as 6 Ratti (750mg) in the case of poisoning and in the case of Nazfud Dam, it can be taken as 4 Jaw (barley). ${ }^{5}$ According to Kabiruddin, 500 mg-1 gm as powder and 1-2 Ratti (125 mg-250 mg) as Kushta can be used. ${ }^{4}$

Mazarrat (Adverse effect and toxicity): It is harmful for urinary bladder and for the individual having cold temperament, $^{7,11}$ it also causes dryness in the stomach. ${ }^{8}$

Musleh (Corrective): Mushk (Moschus moscatus), Gulab (Rosa damascena) or Arq Kewra (Pandanus tinctorius) can be used to counter its adverse or harmful effects. ${ }^{4,7}$

Badal (Substitute): Zabarjad (peridot) can be used as a substitute in case of poisoning and Gil-e-Makhtoom or Marjan (coral) for diarrhoea. $6,7,8,10$

\section{Specifications of Emerald}

The chemical formula of emerald is 3BeO.Al2O3 $6 \mathrm{SiO} 2$. It possesses $12-13 \%$ Be with a specific gravity of 2.6-2.8, Mohs hardness of 7.5-8, and refractive index of 1.57-1.58.12 The most common treatment to enhance the quality of the stone is oiling filler along with oil. Scientists have synthesised this gemstone many times in the laboratory but the first commercial synthetic emerald was synthesised by Carroll Chatum in 1940.

\section{Purification of Emerald}

The purified form of emerald for the treatment purpose is obtained by putting in a poultice of Gmelina asiatica in an earthen shell sealed with a mud smeared cloth and by giving heat of 10 cow dung cakes. ${ }^{13}$

Compound Formulation: Kushta Zumurrud, Khamīra Gaozaban Ambari Jawharwala, Jawarish Aamla Lulvi etc (Table 1).

Table I.Compound Formulation of Emerald (Zumurrud), their Dosage and Indications

\begin{tabular}{|c|c|c|c|c|}
\hline S. No. & $\begin{array}{l}\text { Compound } \\
\text { Formulation }\end{array}$ & $\begin{array}{c}\text { Form of } \\
\text { Zumurrud Used }\end{array}$ & $\begin{array}{l}\text { Dosage/ Route of } \\
\text { Administration }\end{array}$ & Indication \\
\hline 1. & $\begin{array}{l}\text { Habb-i-Jawahar } \\
\text { Muwallif }^{14}\end{array}$ & Zumurrud & 2-5 g/orally & $\begin{array}{l}\text { It has tonic, astringent, expectorant, wound } \\
\text { healing properties and is used for tuberculosis } \\
\text { and diarrhoea }\end{array}$ \\
\hline 2. & Jawaharmohra ${ }^{15}$ & Zumurrud & $60-120$ gm & $\begin{array}{l}\text { It is a general tonic and has analgesic property. } \\
\text { It is used for the treatment of weakness of } \\
\text { vital organs, epilepsy etc. }\end{array}$ \\
\hline 3. & $\begin{array}{l}\text { Jawarish Aamla } \\
\text { Lulvi }^{16}\end{array}$ & $\begin{array}{l}\text { Zumurrud } \\
\text { Mahlool }\end{array}$ & $\begin{array}{l}6 \mathrm{~g} \text { after meal/ } \\
\text { orally }\end{array}$ & $\begin{array}{c}\text { Bilious diarrhoea, hepatargia, stomach } \\
\text { weakness, cardiac weakness, palpitation etc. }\end{array}$ \\
\hline 4. & $\begin{array}{l}\text { Kushta } \\
\text { Zumurrud }{ }^{15,17,18}\end{array}$ & Calx & $\begin{array}{l}30 \mathrm{mg} ; \\
60-125 \mathrm{mg}\end{array}$ & $\begin{array}{l}\text { It has heptatonic, cardiac tonic and is used for } \\
\text { hepatargia, renal weakness, vesical weakness, } \\
\text { frequency of urination, } \\
\text { excessive urination. }\end{array}$ \\
\hline 5. & $\begin{array}{l}\text { Kushta Marjan } \\
\text { Jawahar wala }{ }^{9}\end{array}$ & Zumurrud & $60 \mathrm{mg} /$ orally & $\begin{array}{l}\text { It is used to cure weakness of the brain, } \\
\text { cardiac weakness, cough, coryza, catarrh, and } \\
\text { headache. }\end{array}$ \\
\hline 06 & $\begin{array}{l}\text { Khamīra Gaozaban } \\
\text { Ambari Jawhar } \\
\text { wala }{ }^{15}\end{array}$ & Zumurrud & 3-5 g/ orally & $\begin{array}{l}\text { It is used to cure weakness of the brain, } \\
\text { cardiac weakness, palpitation, restlessness, } \\
\text { melancholia, } \\
\text { nerve weakness, chronic catarrh }\end{array}$ \\
\hline 07 & $\begin{array}{l}\text { Khamira } \\
\text { Zumurrud }^{19}\end{array}$ & $\begin{array}{l}\text { Zumurrud } \\
\text { Saeda }\end{array}$ & 5 g orally & $\begin{array}{l}\text { Cardiotonic, exhilarant, antianxiety, and } \\
\text { palpitation }\end{array}$ \\
\hline
\end{tabular}




\begin{tabular}{|c|c|c|c|c|}
\hline 08 & $\begin{array}{c}\text { Kushta Marjan } \\
\text { Jawaharwala,15 }\end{array}$ & $\begin{array}{c}\text { Zumurrud } \\
\text { powder }\end{array}$ & $60-120 \mathrm{mg}$ & $\begin{array}{c}\text { It is a general tonic and is used for weakness of } \\
\text { the brain, cardiac weakness, restlessness, and } \\
\text { chronic catarrh. }\end{array}$ \\
\hline 09 & Kushta Zumurrud ${ }^{15}$ & $\begin{array}{c}\text { Zumurrud } \\
\text { powder }\end{array}$ & $30 \mathrm{mg} /$ orally & $\begin{array}{c}\text { It is used for hepatargia, cardiac weakness, } \\
\text { cough, and excessive micturition. }\end{array}$ \\
\hline 10 & $\begin{array}{c}\text { Majun Murawweh } \\
\text { al Arwah }\end{array}$ & & $\begin{array}{c}1 \mathrm{~g} \text { with ma'ul } \\
\text { laham } 60 \mathrm{ml} / \text { orally }\end{array}$ & $\begin{array}{c}\text { It is used for sexual weakness and weakness of } \\
\text { vital organs. }\end{array}$ \\
\hline 11 & Ma'jun Tila $^{9}$ & $\begin{array}{c}\text { Zumurrud } \\
\text { Fine powder }\end{array}$ & $\begin{array}{c}3 \mathrm{~g} \text { orally with } \\
\text { vehicle }\end{array}$ & $\begin{array}{c}\text { Cardiac tonic, mood creator and used for } \\
\text { palpitation and faintness }\end{array}$ \\
\hline 12 & $\begin{array}{c}\text { Qurs Dhayabitus } \\
\text { Khas }^{15}\end{array}$ & Calx & $1-2 \mathrm{~g}$ & Diabetes \\
\hline
\end{tabular}

\section{Conclusion}

Zumurrud (emerald) is a precious gemstone known under Navratnas. It is used as a medicine since time immemorial. It is one of the preferred drugs of Unani physicians to treat cardiac, brain, and liver diseases. However, there are no scientific studies regarding its pharmacological properties, so this paper is compiled for highlighting the hidden medicinal uses of the stone and further necessary pharmacological researches to validate its medicinal properties as mentioned by various Unani physicians.

\section{Acknowledgement}

The authors are thankful to the Assistant Director, In-charge, RRIUM, Srinagar for her encouragement and for providing the necessary facilities in the institute to write this article.

\section{Conflict of Interest: None}

\section{References}

1. Kalam MA, Rahman S. Lajward (Lapis lazuli): Medicinal Potential of a High-Value Gemstone in the Light of Unani Medicine, IJPPR.Human. 2020;20(1):389-99.

2. Seraj S, Monjur-E-Khudha M, Aporna SA, Khan SH, Islam F, Jahan FI, Mou SM, Khatun Z, Rahmatullah M. Use of Gemstones for Preventive and Curative Purposes: a Survey among the Traditional Medicinal Practitioners of the Bede Community of Bangladesh. Am Eur I Sustain Agri. 2011; 5(2):263-9. [Google Scholar]

3. Baitar I. Al-Jami Li-Mufradatul Advia wa Al-Aghzia. Vol. 2. New Delhi: Central Council for Research in Unani Medicine; 2000. p. 348, 349.

4. Kabiruddin M. Makhzanul Mufradat. New Delhi: Idara Kitabus Shifa; 2014. p. 240, 241.

5. Ghani N. Khazainul Advia. New Delhi: Idara Kitabus Shifa; 2011. p. 765, 766.

6. Khan A. Muheet-i-Azam. Vol 2. New Delhi: Central Council for Research in Unani Medicine; 2013. p. 78890.

7. Hakim A. Bustanul Mufradat. New Delhi: Idara Kitabu
Shifa; 2011. 112 p.

8. Rafiquddin M. Kanzul Advia Mufrada. AMU, Aligarh: University Publication Unit; 1985. p. 389, 390.

9. Kabiruddin M. Bayaz-i-Kabir. 5th ed. Vol. 2. New Delhi, India; Aijaz Publishing House; 1934. p. 426, 430, 452, 453.

10. Ashraf MH. Makhzanul Mufradat Ma Murakkabat wa Khwasul Advia. New Delhi: Aijaz Publishing House; 2011. 75 p.

11. Nasir MAH. Mufradat Nasiri Mae Takmila. India: Qaisari Publication. YNM. 63 p.

12. Available at https://geology.com $>$ gemstones (Accessed on $19 / 05 / 2021$ )

13. Anandan AR, Thulasimani. Siddha Materia Medica (Mineral and Animal Kingdom). Department of Indian Medicine and Homeopathy, Chennai; 1985. 381 p.

14. National Formulary of Unani Medicine. Part III. New Delhi: Central Council for Research in Unani Medicine; 2001. 20 p.

15. National Formulary of Unani Medicine. Part I. New Delhi: Central Council for Research in Unani Medicine; 2006. p. 46, 72, 78, 110, 231.

16. National Formulary of Unani Medicine. Part VI. New Delhi: Central Council for Research in Unani Medicine; 2011. $56 \mathrm{p}$.

17. National Formulary of Unani Medicine. Part V. New Delhi: Central Council for Research in Unani Medicine; 2008. $59 \mathrm{p}$.

18. Qarabadin Sarkari. New Delhi: Central Council for Research in Unani Medicine. $79 \mathrm{p}$.

19. Qarabadin Majidi. Delhi: Alami Printing Press. YNM. $84 \mathrm{p}$. 